\title{
岡山県東兒町番田產セイチョウ石及び コウリチョウ石の生長関係について
}

On the Growth Relations of Orthoclase and Adularia from Banda, Tôji- Machi, Okayama Prefecture.

\author{
富 阪 武 士* (Takeshi Tomisaka) \\ 逸見吉之助** (Kitinosuke Henmi)) \\ 淮 谷 五 郎* (Gorô Shibuya)
}

\section{1.はしがき}

著者の一人 (K. H.) は岡山県東览町附近のクロウンモーカコウ岩中に不 規則に分布するぺグマタイト脈を見出したが，とくに番田のペグマタイト脈 から多数のセイチョウ石の良晶を採集した。このセイチョウ石 (orthoclaseperthite）はその後のコウリチョウ石の形成によつて被覆され，セイチョウ 石上のコウリチョウ石の overgrowth がよく観察される。かかる例は時折 見受けられるようで西るが（たとえば苂城県山の尾のペグマタイトの晶洞中 亿生長するセイチョウ石), 本試料は結晶面がよく発達している良晶のため, アルカリーチョウ石生成の機構を考察する上に極めて好ましい試料と考え,て てに報告する次第である。

\section{2. 産状}

本試料の産地は岡山県児島郡東览町 (旧鉾立村) 番田にあり, 相引部落の 北西 $500 \mathrm{~m}$, 海拔 $50 \mathrm{~m}$ の地点である。附近一帯はクロウンモーカコウ岩よ りなり，てれを貫いてセキエイ脈が数箅所に発達している。明治の末年にス イショウを目的とした探鉱が行われ，所々に掘り跡が見られる。

てれらの探鉱跡のらち最上部の坑道の東坑口附近には，七キエイ脈に接近 したカコウ岩中に走向 $\mathrm{N} 80^{\circ} \mathrm{E}$, 傾斜 $45^{\circ} \mathrm{NW}$, 巾 $20 \sim 30 \mathrm{~cm}$ の一条のペ グマタイト脈があつて, 自形のチョウ石はその晶洞中に自形七キエイと共生 している。またてのペグマタイト脈はセキエイ脈によつて切られている。セ

\footnotetext{
* 山口大学交理学部地学教室

** 岡山大学理学部地学教室
} 
ー 40 一 セイチョウ石及びェウリチョウ石の生長関係について

キエイ脈の西坑口側にもとのペグマタイトの延長と思われる細脈が認められ るが，ての部分のチョウ石はコウリチョウ石の被覆が東坑口のもの比して 薄く、ときに全くてれを欠く場合もする。チョウ石と共生するセキエイは黒
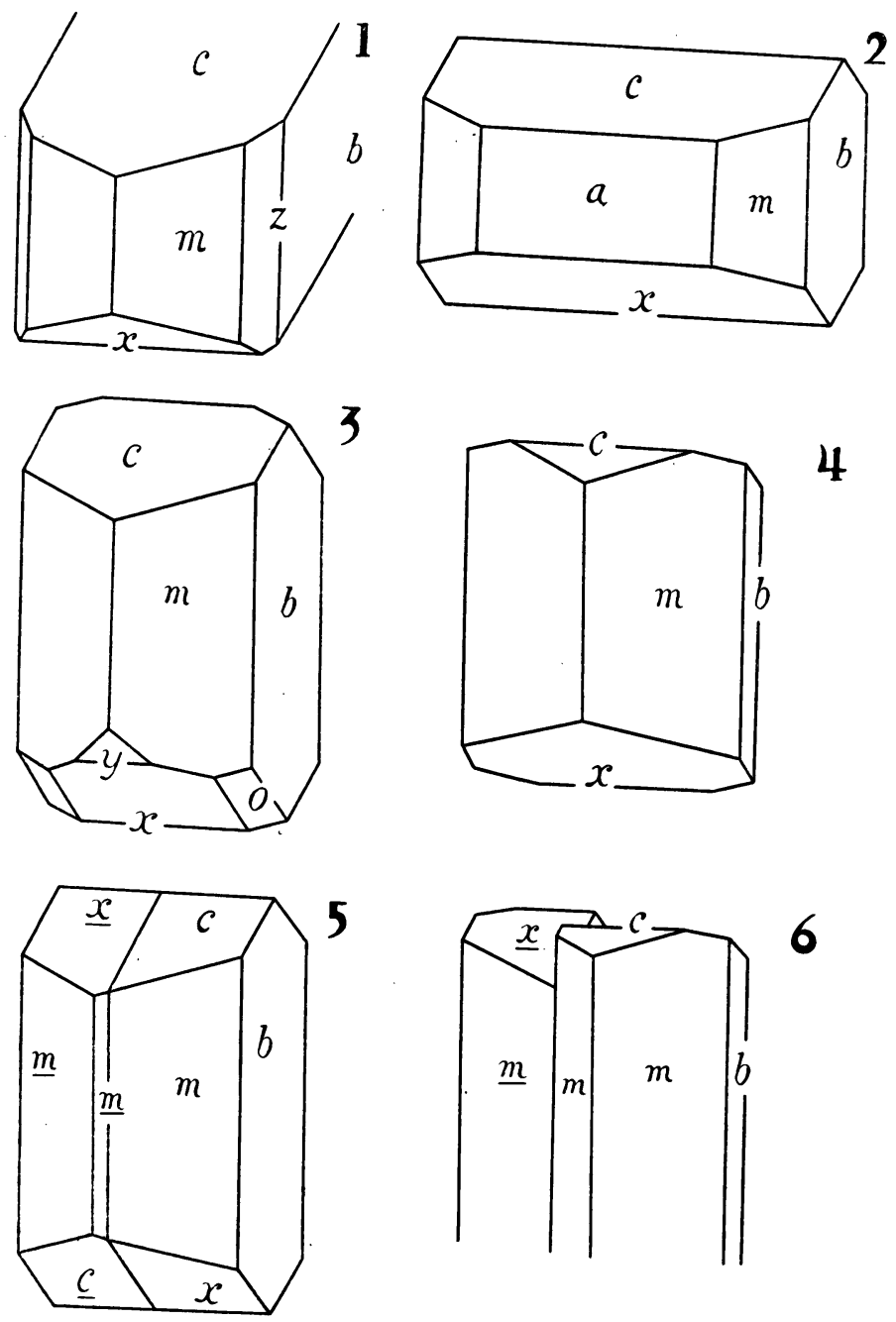

第 1〜4 図 番田産セイチョウ石単晶

第 5, 6 図同上カルルスバッド式双晶 
色，白色または淡灰色の杜状小結晶で錐面はしばしば三方的である。ときに 三方錐を有する, 先端が細くなつた柱状をなす長さ $5 \mathrm{~cm}$ 前後の黄緑色のセ キエイ結晶を産するてとがある。
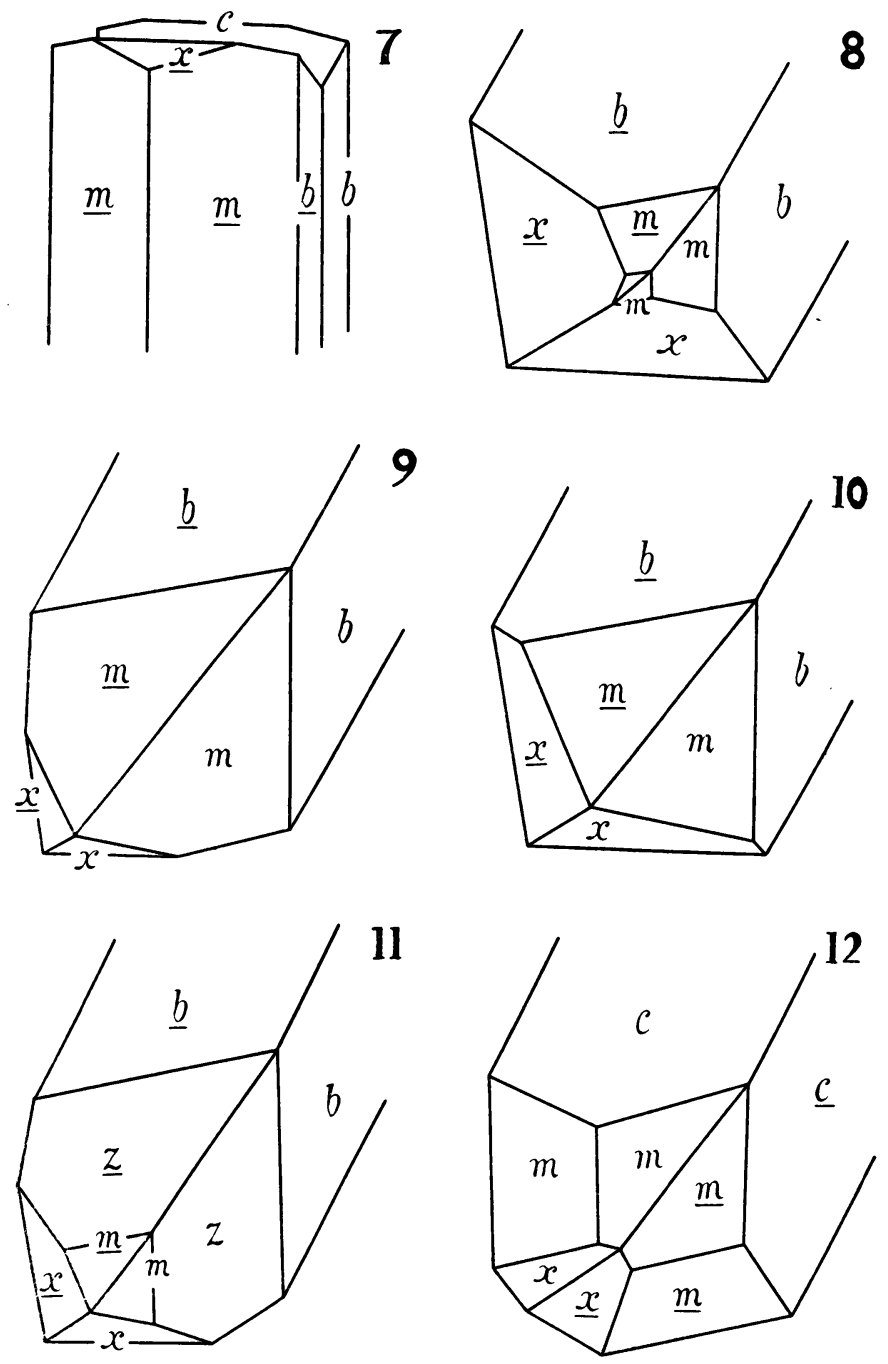

第 7 図番田産セイチョウ石カルルスバッド式双晶

第 8〜12 図同上 バベ式双晶 
ー 42 — セイチョウ石及びュゥリチョウ石の生長関係について

\section{3. 晶癖と双晶}

大半の結晶は双晶をなしているが，一見一個の結晶のよらな形態を呈して いるものが多んので, ててではてのような双晶体をも単結晶として記述す る。

大きさは大小多様で西るが, 採集した最大の単結晶は $\mathrm{a}$ 軸 $3 \mathrm{~cm}, \mathrm{~b}$ 軸 2 $=\mathrm{m}, \mathrm{c}$ 軸 $2 \mathrm{~cm}$, 重量 $13 \mathrm{~g}$ であb, 双晶体の最大のものは一稜 $2 \sim 3 \mathrm{~cm}$, 長 さ $5.5 \mathrm{~cm}$ の四角柱状で重量 $60 \mathrm{~g}$ 几及ぶ。結晶面として次の諸面が認めら れる。

$$
c\{001\}, b\{010\}, a\{100\}, z\{130\}, m\{110\}, y\{\overline{20} 1\}, x\{\overline{1} 01\}, o\{\overline{1} 11\} .
$$

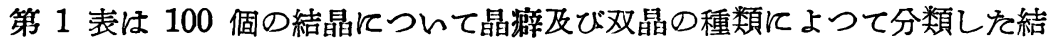
果を示す。第 1１5 因に代表的な試料の結晶図を示した。実際の結晶のう
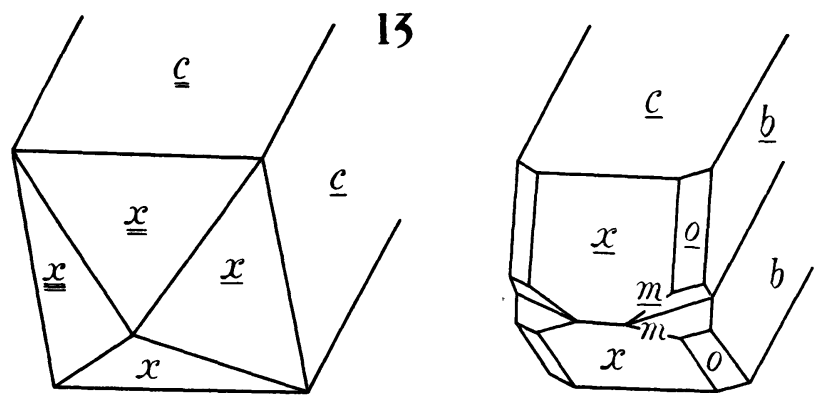

14

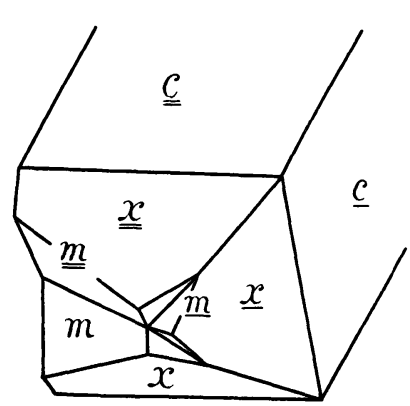

15

第 13 図番田産セイチョウ石四連晶

第 14 図 同上マネバッ八式双晶

第 15 図同上バベノーマネバッハ三連晶 
ちとはより複雑なものも見られる。バベノ双晶では，㾁とんどが $c$ 面に関し て $\{001\}\{100\}$ の鏈角側にのみ端面を示してんて, 鋭角側て端面を示してん る例は極めて稀である。比較的例数の多いバベノーマネバッ八式三連晶は,す ぺてが鈍角側にのみ端面を示しているてとと共に注目すべき事実でする。

\section{4. コウリチョウ石の被覆}

セイチョウ石の大部分はコウリチョウ石によつて被覆されまを，コウリ チョウ石はセイチョウ石を核として生成し，特殊な連晶関係が見られる。セ イチョウ石核を有しないコウリチョウ石は認められない。被覆の程度は個体

第 1 表 番田産セイチョウ石の双晶の種類と晶癖

\begin{tabular}{|c|c|c|c|c|}
\hline 双 & 接合面 & 晶 & 個体数 & 結晶図 \\
\hline 単 & & $\begin{array}{lllll}\mathbf{a} & \text { 軸 } & に & \text { 伸 } & \text { 長 } \\
\mathbf{b} & \text { 軸 } & に & \text { 伸 } & \text { 長 } \\
\mathbf{c} & \text { 軸 } & \text { に } & \text { 伸 } & \text { 長 } \\
\text { そ } & \text { の } & \text { 他, } & \text { 不 } & \text { 明 }\end{array}$ & $\begin{array}{r}2 \\
5 \\
5 \\
14\end{array}$ & $\begin{array}{l}1 \\
2 \\
3 \\
4\end{array}$ \\
\hline カルルスパッド式 & $\begin{array}{l}\{010\} \\
\{100\}\end{array}$ & & $\begin{array}{l}8 \\
3 \\
1\end{array}$ & $\begin{array}{c}5,6 \\
7\end{array}$ \\
\hline パ ベノ式 & $\begin{array}{l}* \\
\text { (ii) }\end{array}$ & $\begin{array}{l}\text { 端面 } x \text { を主とする } \\
\text { 端面 } m \text { を主とする } \\
\text { 端面 } x, m \text { を主とする } \\
\text { 端面 } z \text { を主とする }\end{array}$ & $\begin{array}{r}13 \\
12 \\
9 \\
3 \\
3\end{array}$ & $\begin{array}{r}8 \\
9 \\
10 \\
11 \\
12\end{array}$ \\
\hline バべノ式四連晶 & & 端面 $x$ を主とする & 1 & 13 \\
\hline マネバッハ式 & & 端面 $x$ を主とする & 1 & 14 \\
\hline $\begin{array}{l}\text { パ゚ノ式 複 } \\
\text { マネバッハ式，合 }\end{array}$ & & 端面 $x$ を主とする & 20 & 15 \\
\hline
\end{tabular}

計 100

* (i ) 端面か; $\{001\} \hat{\{100\}}$ の鈍角側に現れているすの

(ii) 端面か： $\{001\}\{100\}$ の鋭角側に現れているすの 


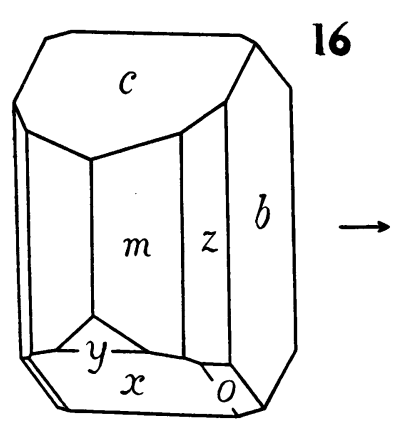

第16図セイチョウ石型結晶

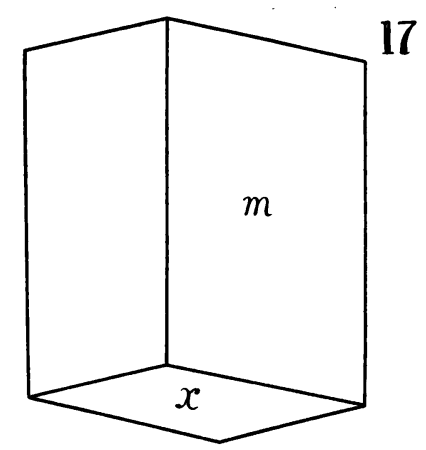

第 17 図 コウリチョウ石型結晶
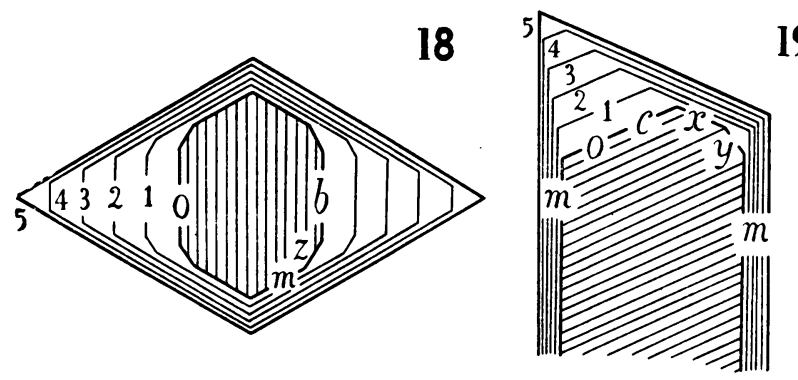

19

第18,19図 コウリチョウ石の被覆によつてセイチョウ石型(陰影部) からコウリチョウ石型の形態へ漸移するようすを断面で 示す。18. $\mathrm{c}$ 軸に垂直な断面。19. $\mathrm{b}$ 軸に 垂直な断面。

によつて相異するが，核をなすセイチョウ石の大きさと一定つ関係を示し， セイチョウ石の大きい症ど被覆の厚さの絶対値は大であるが，核江対する比 率は小さく，セイチョウ石が小さんときは，絶対值は小であるが比率として は大をくなっている。

コウリチョウ石とセィチョウ石とは晶癖を異にし，コウリチョウ石は第 17 因の如く $m, x$ の面が大きく $, b, c$ の面を欠くか存在する場合でも著し く小さん。番田産のセイチョウ石単結晶は一般に第 16 四のような形態を示 す。第 16 目のセイチョウ石を核としてその上にコウリチョウ石が被覆して 生長すると, 生長につれて漸次形態を恋じ, 最後に第 17 図のよらなコウリ チョウ石の形態に移行する。第 18 圀はc 軸に垂直な断面でそのようすを 示し，第 19 因は b 軸と垂直な断面でその生長の偅跡を示したものである。 
因に示した如く，一般にコウリチョウ石の被覆は核をなすセイチョウ石の結 晶面によつて異り, $b$ 面上がもつとも著しく,つんで $c$ 面上で著しん。 $m$, $x$ の面上の被覆は薄的。その結果 $m, x$ の面は大きく現われ, $b, c$ の面は 消失する傾向がある。その他の面では $y$ 面はもつとも消失の傾向が著しく, $c, z, o$ の諸結晶面は明らかで疗ん。

\section{5. 化学組成, 比重及び光学的性質}

番田産セイチョウ石及びコウリチョウ石の化学組成, 比重及び光学的性 質は第 2 表の如くである。てれらの実験結果は，それぞれセイチョウ石 (orthoclase-perthite), コウリチョウ石と従来命名されているものと差異は をん。第 3 表に Norelco X 線廻折計数装置による廻折線の結果を示した。 とくに、コウリチョウ石につんては Tavetsch (スイス) 産コウリチョウ石 を比較のため同時に表示した。両者は X 線粉末迴折線のみならず光学性, 化学成分子注瘏類似の值を示してんる。

第 2 表 番田産コウリチョウ石とセイチョウ石の 化学組成, 比重及び光学的性質

\begin{tabular}{|c|c|c|c|}
\hline & \multirow{2}{*}{ コウリチョウ石 } & \multicolumn{2}{|c|}{ セイチョウ石 } \\
\hline & & I & II \\
\hline $\mathrm{SiO}_{2}$ & $65.13 \%$ & $65.34 \%$ & $65.50 \%$ \\
\hline $\mathrm{Al}_{2} \mathrm{O}_{3}$ & 18.07 & 19.66 & 19.20 \\
\hline $\mathrm{Fe}_{2} \mathrm{O}_{3}$ & 0.50 & 0.54 & 0.73 \\
\hline $\mathrm{MgO}$ & 0.70 & 0.29 & $\operatorname{tr}$ \\
\hline $\mathrm{CaO}$ & 0.61 & 0.36 & 0.46 \\
\hline $\mathrm{K}_{2} \mathrm{O}$ & 14.28 & 10.41 & 10.50 \\
\hline $\mathrm{Na}_{2} \mathrm{O}$ & 1.18 & 3.67 & 3.52 \\
\hline $\mathrm{H}_{2} \mathrm{O}(+)$ & 0.35 & 0.58 & 0.37 \\
\hline $\mathrm{H}_{2} \mathrm{O}(-)$ & 0.08 & - & 0.03 \\
\hline Total & $100.90 \%$ & $100.85 \%$ & $100.31 \%$ \\
\hline $\mathrm{Ab} \stackrel{\text { Or : }}{:}$ An & $\begin{array}{c}86.12: \\
10.80: 3.08\end{array}$ & $\begin{array}{c}63.91: \\
34.24: 1.85\end{array}$ & $\begin{array}{c}64.69: \\
32.92: 2.39\end{array}$ \\
\hline & $\begin{aligned} \mathrm{G}_{4^{\circ}}^{16^{\circ}} & =2.578 \\
\hat{\mathrm{aX}} & =4^{\circ} \sim 5^{\circ}\end{aligned}$ & & $\begin{aligned} \mathrm{G}_{4^{\circ}}^{16^{\circ}} & =2.586 \\
\hat{\mathrm{aX}} & =7^{\circ} \sim 8^{\circ}\end{aligned}$ \\
\hline
\end{tabular}




$$
\begin{array}{r|r}
\alpha=1.518 & \alpha=1.522 \\
\beta=1.523 & \beta=1.525 \\
\gamma=1.524 & \gamma=1.528 \\
2 \mathrm{~V}=(-) 56^{\circ} & 2 \mathrm{~V}=(-) 51^{\circ} \\
(\perp(010)) & (\perp(010))
\end{array}
$$

\begin{tabular}{|c|c|c|c|c|c|}
\hline \multicolumn{2}{|c|}{ コウリチョウ石(番田) } & \multicolumn{2}{|c|}{ ユウリチョウ石(スイス) } & \multicolumn{2}{|c|}{ セイチョウ石(番田) } \\
\hline$d(\AA)$ & $I$ & $d(\AA)$ & $I$ & $d(\AA)$ & $I$ \\
\hline 6.598 & 5 & 6.639 & 7 & 6.682 & 5 \\
\hline 6.478 & 18 & 6.559 & 9 & 6.511 & 11 \\
\hline 5.906 & $4(B)$ & 5.905 & $3(\mathrm{~B})$ & 5.906 & $3(\mathrm{~B})$ \\
\hline \multirow[t]{2}{*}{4.230} & 18 & 4.230 & 10 & 4.249 & 18 \\
\hline & & & & 4.040 & 6 \\
\hline 3.952 & 13 & 3.968 & 10 & 3.952 & 10 \\
\hline 3.850 & 3 & 3. 867 & 5 & 3.867 & 4 \\
\hline 3.786 & 35 & 3.786 & 19 & 3.786 & 35 \\
\hline 3. 667 & 2 & 3. 670 & 4 & 3.678 & 5 \\
\hline 3.619 & 7 & 3.633 & 7 & 3.633 & 5 \\
\hline 3.585 & 7 & 3.597 & 7 & 3.585 & 4 \\
\hline 3.562 & 4 & 3.548 & 5 & 3.548 & 3 \\
\hline 3.480 & 26 & 3.470 & 22 & 3.472 & 23 \\
\hline \multirow[t]{2}{*}{3.315} & 54 & 3.310 & 64 & 3.323 & 48 \\
\hline & & & & 3. 302 & 24 \\
\hline \multirow[t]{3}{*}{3.243} & 200 & 3.243 & 200 & 3.232 & 108 \\
\hline & & & & 3.197 & 25 \\
\hline & & & & 3.175 & 5 \\
\hline 3.003 & 25 & 2.995 & 17 & 3.008 & 30 \\
\hline 2.939 & 4 & & & 2.931 & $6(\mathrm{~B})$ \\
\hline \multirow[t]{2}{*}{2.907} & 20 & 2.907 & 14 & 2.907 & 15 \\
\hline & & & & 2.899 & 12 \\
\hline 2.775 & 8 & 2.775 & 7 & 2.775 & $7^{\circ}$ \\
\hline 2.611 & 6 & 2.611 & 7 & 2.612 & 5 \\
\hline 2.581 & 15 & 2.581 & 12 & 2.582 & 13 \\
\hline $2 \cdot 564$ & 6 & 2.557 & 8 & 2.557 & 6 \\
\hline 2.520 & 4 & 2.529 & 3 & 2.529 & 4 \\
\hline 2.492 & 3 & 2.488 & 2 & & \\
\hline
\end{tabular}

第 3 表 $\mathrm{X}$ 線粉末廻折線 


\begin{tabular}{cc|cc|cc}
2.423 & 4 & 2.423 & 5 & 2.419 & 4 \\
2.386 & 4 & 2.389 & 3 & 2.388 & 4 \\
2.332 & 4 & 2.333 & 8 & 2.328 & 6 \\
2.167 & 20 & 2.167 & 11 & 2.171 & 14 \\
2.127 & 6 & 2.132 & 5 & 2.127 & $5(\mathrm{~B})$ \\
2.069 & $2(\mathrm{~B})$ & 2.076 & $2(\mathrm{~B})$ & 2.071 & 3 \\
2.056 & 3 & 2.058 & 2 & 2.058 & 2 \\
2.011 & 5 & 2.016 & 3 & 2.014 & 4 \\
1.976 & 7 & 1.997 & 4 & 1.977 & 6 \\
1.927 & 4 & 1.927 & 7 & 1.933 & 5 \\
& & & & 1.914 & $2(\mathrm{~B})$ \\
1.890 & 3 & 1.893 & 1 & 1.892 & $2(\mathrm{~B})$ \\
1.859 & 8 & 1.868 & 3 & 1.859 & 7 \\
1.804 & 18 & 1.804 & 10 & 1.801 & 16 \\
1.774 & $2(\mathrm{~B})$ & 1.774 & 2 & & \\
1.630 & $4(\mathrm{~B})$ & 1.631 & $4(\mathrm{~B})$ & 1.635 & 2 \\
1.595 & 2 & 1.598 & 3 & 1.597 & 2 \\
1.571 & 8 & 1.570 & 4 & 1.572 & 3 \\
\hline
\end{tabular}

Norelco X 線廻折計数装置による. 使用条件： $\mathrm{Cu} K \alpha, \mathrm{Ni}$ フィルター, $30 \mathrm{KV}, 15 \mathrm{~mA}$, scanning factor 8-1-4, 1\%/分

\section{6. 結語}

番田産のセイチョウ石は顕微鏡下において、症、（100）に平行なりウチョ ウ石の葉片構造が観察され，てのソウチョウ石は集片アルバイト双晶をなし ている。一方，コウリチョウ石の(001)の薄片を検鏡すると，一般に極めて 新鮮で㐫るが，ときに，セイチョウ石の (010) 飞亞平行的に巾 $0.01 \mathrm{~mm}$ 内 外のコウリチョウ石の薄層が積み重なつて生長し，かつ各薄層もお互いに多 少平行位置からホれてんて,そのために，一見僅少を斜消光を示し三科晶系に 属するコウリチョウ石と見誤る場合がある。最近 A. Köhler') や F. Laves ${ }^{2)}$ らによつて三斜晶系に属するコウリチョウ石が記載され，単斜晶系のコウリ チョウ石との関係につんて論ぜられているが，本コウリチョウ石は光学的に る $\mathrm{X}$ 線的にも笚斜晶系に属するものである。

G. Kalb ${ }^{3)}$ はコウリチョウ石には生成条件を反映する二型が存在するとと を産状と晶癖から主張している。をた，渡辺武男4) は Kalb のん5二型は化

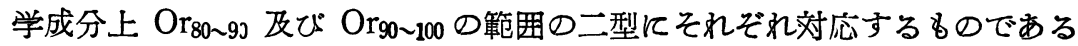


と述べている。Ab 成分の固溶度の大小といら観点から，かりに，前者を高温 型,後者を低温型と称すると, 当産地のコウリチョウ石はその化学組成上高温 型に相応する。ただし，ててでいら二型は結晶構造的な意味を含んでいない。

T. F. W. Barth ${ }^{5}$ は A. W. Lawson6) 飞よって熱力学の基礎の上に立 つて示された二成分系の平衡関係の理論的取扱方法を使用して，KAl $\mathrm{KAi}_{3} \mathrm{O}_{8^{-}}$ $\mathrm{NaAlSi}_{3} \mathrm{O}_{8}$ 系の混和度と結晶化温度との二次元平衡田を作製してんる。

Barth とは別r, N. L. Bowen と O. F. Tuttle $\mathrm{O}_{8}$ 系列の熱水合成実豎を行 $ん, \mathrm{Or}_{8} \sim \mathrm{Or}_{75}$ の範囲の結晶化温度曲線を決定 した。この二種の曲線を比較すると $0_{65}$ 以下ではかなり著しい相異が見ら れるが，それ以上の場合は完全に一致してんる。Bowen らは $\mathrm{Or}_{75}$ 以上の 組成のものにつんての合成に成功していないが, 外挿して得られる曲線は, また Barth の曲線と良く一致する。これらの四表に従らと, 番田産のセイ チョウ石の結晶化温度は $590^{\circ} \sim 600^{\circ} \mathrm{C}$ を示し，コウリチョウ石のそれは $380^{\circ} \mathrm{C}$ を示している。ての大きな温度差より，セイチョウ石の生成後引を 続いてコウリチョウ石の生成が行われたものと考えるととは困難なようであ る。したがつて，セイチョウ石の生成後，より低温の別種の溶液が同一径路 を上昇して来てコウリチョウ石の overgrowthをるたらしたものとするのが 妥当と思われ，当ペグマタイト脈を後期のセキエイ脈が切つているととと関 連があるものと考えられる。乙の考えを支持する他の一つの根拠として，七 イチョウ石とコウリチョウ石の境界が極めて鮮明であるてとが挙げられる。

晶澼や双晶の多様性の原因に関しては，なお資料を豊富にし稿を改めて考 察したん。

Norelco X 線廻折計数装置の使用にあたり便宣を与えられた東京大学伊藤 貞市教授ならびに飯高洋一氏に謝意を表する。また東京大学片山信夫教授は 種々有益な御教示を与えられた。こてに厚くお礼申し上げる。

\section{女 䰚}

1) Köhler, A. : Neues Jahrbuch f. Min., (A) 5-8, 49 (1949).

2) Laves, F. : Jour.Geol., 58, 548 (1950).

3) Kalb, G. : Centralbl. f. Min., (A) 449 (1924).

4）渡辺武男：地䓄雑， 41，531（1934）.

5) Barth, T. F. W. : Neues Jahrbuch f. Min., (A) 82, 143 (1951).

6) Lawson, A. W. : Jour. Chem. Phys., 15, 831 (1947).

7) Bowen, N. L. and Tuttle, O. F. : Jour. Geol., 58, 485 (1950). (1956 年 4 月 16 日受理) 